Mediterranean Aquaculture Journal 2014 (6); 30-39.

\author{
Original Article
}

\title{
Evaluation of Biochar as Abio filter for Application in Commercial Fish Culture System
}

Sorur $^{1}$, T. M.; El-Baramawy ${ }^{1}$, N. M.; El - Sharkawey ${ }^{2}$, H, M. G. and Kord ${ }^{1}$, M. M. I.

1- Fish Husbandry, Fac. of Agric. Saba Basha Alex. Univ.

2- Central Lab. of Agric. Environ. Agriculture Research Institute

\begin{abstract}
Biochar is commonly used for absorption of heavy metals in the soils and water and so decreasing its level in fish meat with improvement of growth performance, productivity and hatchability as well as immunity of the fish against different fish diseases. The present work was conducted a fish farm is Metobase area in Kafr El-Sheikh governorate during season 2014. The period extended from January to May at the department of fish production Fac. of Agric. Saba Basha, Alexandria University. The biochar was prepared by burning of the rice bran at $300{ }^{\circ} \mathrm{C}$ using circular cylinder rotated by anaerobic motors. In our investigation, a total number of 162 broodstock of Oreochromis niloticus fish that were collected from private fish farm at Kafr El-Sheikh governorate, Egypt. The enhancement of aeration of aquaculture occurred by air blowers and agriculture machine, and the water column of ponds in both was about $1.5 \mathrm{~m}$. The aim of this study is to investigate the importance of biochar in growth performance and production efficiency of Nile tilapia as well as protective effects of heavy metal pollution in the aquaculture environment, product of fish and finally the histopathological alterations. Our results concluded that, the addition of biochar to the fish production ponds decrease the level of heavy metals and reduced its accumulation in fish organs especially the saw dust biochar, followed by rice husk biochar.
\end{abstract}

Key words: Biochar, Oreochromis niloticus, Pollution, Heavy metals, Histopathology

Received: 3 October 2014

Accepted: November 2014

Corresponding author: El-Baramawy ${ }^{1}$, N. M.

Fish Husbandry, Faculty of Agriculture Saba Basha

Alexandria University

Alexandria, Egypt

e-mail: nagy96@hotamil.com

Copyright : All rights reserved to Mediterranean International Aquaculture and Environment Society (MAEPS) 


\section{Introduction}

Biochar is a fine-grained charcoal high in organic carbon and largely resistant to decomposition. It is produced from pyrolysis of plant and waste feedstocks. It's commonly used as a filter for the water especially drinking water or fish farm water. As a soil amendment, biochar creates a recalcitrant soil carbon pool that is carbonnegative, serving as a net withdrawal of atmospheric carbon dioxide stored in highly recalcitrant soil carbon stocks. The enhanced nutrient retention capacity of biochar-amended soil not only reduces the total fertilizer requirements but also the climate and environmental impact of croplands. Char-amended soils have shown 50 - 80 percent reductions in nitrous oxide emissions and reduced runoff of phosphorus into surface waters and leaching of nitrogen into groundwater. As a soil amendment, biochar significantly increases the efficiency of and reduces the need for traditional chemical fertilizers, while greatly enhancing crop yields. Renewable oils and gases coproduced in the pyrolysis process can be used as fuel or fuel feed-stocks. Biochar thus offers promise for its soil productivity and climate benefits (Major et al., 2010; Vaccari et al., 2011; Reverchon et al., 2014; Zhang and Sun, 2014). Using biochar as a soil fertilizers improved the plant growth, soil fertility with reduction of the heavy metal pollution in the agriculture water with and its usage in aquaculture ponds improved the fish growth than the non-fertilized soil or aquaculture ponds with biochar (Schmidt, 2014). Yang et al. (2014) suggested that using of a low-cost Alternanthera philoxeroides biochar (APB) adsorbent for heavy metals contaminated water treatment may have great ecological and environmental significance as it reduces the level of heavy metals such as lead, mercury, copper and other harmful heavy metals. Lim et al. (2014) observed that the using of biochar in aquaculture may potentially alter nitrous oxide $\left(\mathrm{N}_{2} \mathrm{O}\right)$ emission by affecting ammonia-oxidizing and nitrification bacteria, which is determined by the application rate of biochar in soil and water. The means by which biochar improves production response can be attributed to direct effects via biochar-supplied nutrients (Silber et al., 2010), and to several other indirect effects, including: increased nutrient retention; improvements in soil $\mathrm{pH}$; increased soil action exchange capacity (Yamato et al., 2006); effects on Phosphorus and Sulfur transformations and turnover; neutralization of phytotoxic compounds in the soil (Wardle et al., 1998). Biochar improved soil physical properties including water retention; promotion of mycorrhizal fungi (Warnock et al., 2007); and alteration of soil microbial populations and functions (Graber et al., 2010 and Kolton et al., 2011). Given that the biochar-soil-plant-water environment is highly complex, it is difficult to isolate those factors which actually play an instrumental role in 'The Biochar Effect'. To reduce the number of potential factors involved, (Pietikainen et al., 2000), tested whether biochar addition could impact plant growth when nutritional and soil physical aspects of biochar amendment were eliminated, by using a nutrient-poor, wood-derived biochar, under an optimal fertilization and irrigation regime in a greenhouse(Graber et al., 2010). They reported an increase in several plant growth parameters for both plants by using biochartreatment. Environmental pollution represents a major problem in the world, especially in the less developed countries. Egypt is one of those countries which suffer from biosphere pollution (air, soil and water). Agricultural, industrial and sewage wastes, which are discharged into the River Nile, canals and other water resources causing ecological changes in water. Pollutants including heavy metals, pesticides, hydrocarbons that present in polluted water way be accumulated in fish tissues and organs causing severe healthy problems to the consumers.

The aim of this study is to investigate the importance of biochar in prevention of 
heavy metal pollution in the aquaculture environment of either water, product of fish or the decreasing the level of histopathological changes that observed in the fish organs due to heavy metal pollutions. Through study of the level of heavy metals in water, fish products and the histopathological changes resulted in heavy metal pollutions and biochar addition to the fish ponds.

\section{Materials and methods}

Experimental broodstock trial was carried out in fish farm in Metobase area Kafr ElSheikh Governorate in triplicate during 2014. Adult 162 broodstock Oreochromis. niloticus with an average body weight 482.8 $\pm 2 \mathrm{~g} /$ fish were used to evaluate Biochar from different compound as a biofilters for application in commercial fish culture system. Fish were fed on a commercial fish diet containing $28.4 \%$ crude protein. The diet was daily provided with specific feeding ratio of according to body weight and growth stages of fish as described by Eurell et al. (1978) as follow. Feeding ratio for fish about was $4 \%$ of their life body weight.

The biochar filters media of rice husk (RH), saw dust (SD), clay brick dust (CBD) and sand $(\mathrm{S})$ used in this study were collected from the local market. The collected materials were extensively washed with tap water to remove soil and dust. Dry RH and SD were crushed and sieved by $0.5-\mathrm{mm}$ polypropylene sieve for preparing the biochar materials. A pilot-scale diesel pyrolyzer designed at the central Laboratory for Agriculture Climate, with a maximum capacity to process $15 \mathrm{~kg}$ of raw material per batch was used to produce biochar. Carbonization temperatures used for both types of residual biomass were $350^{\circ} \mathrm{C}$. The temperature was increased at a rate of 5 ${ }^{\circ} \mathrm{C} / \mathrm{min}$ until the specific temperature was reached and maintained for $1 \mathrm{~h}$. After that, a cooling down procedure until room temperature was carried out. Biochar filter materials and raw materials were placed in pocket's in three steps media 1,2 and 3 according to Table 1 and Fig1.

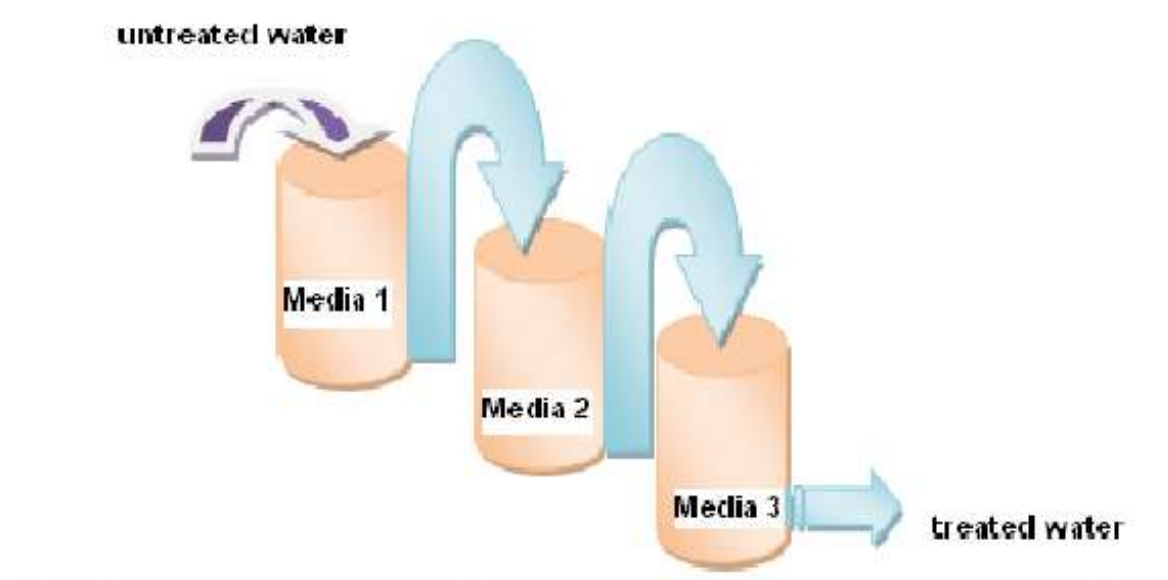

This drawing to illustrate one sample (Group) of the filter used in this study

Fig 1. Illustrate sample (Group) of the filter used in this study 
Table 1. Design of the experiment

\begin{tabular}{|l|c|c|c|}
\hline Groups & \multicolumn{3}{|c|}{ Treatment } \\
\hline & Media 1 & Media 2 & Media 3 \\
\hline Group1 & Sand & Raw rice husk & Raw rice husk \\
\hline Group2 & Sand & Break dust & Biochar saw dust \\
\hline Group3 & Sand & Biochar saw dust & Biochar saw dust \\
\hline Group4 & Sand & Biochar rice husk & Biochar rice husk \\
\hline Group5 & Sand & Break dust & Biochar saw dust \\
\hline Group6 & Sand & Break dust & Biochar rice husk \\
\hline Group7 & Sand & Biochar rice husk & Biochar saw dust \\
\hline Group8 & Sand & Break dust & raw rice husk \\
\hline Group9 & \multicolumn{3}{|c}{ Control } \\
\hline
\end{tabular}

Water samples were collected before treatment and after treatment from different groups to determine the water chemical characteristics ( $\mathrm{pH}, \mathrm{NH} 3$, Dissolved Oxygen and $\mathrm{EC})$ and heavy metals $(\mathrm{Pb}, \mathrm{Cd}, \mathrm{Zn}, \mathrm{Cu}$, $\mathrm{Hg}, \mathrm{Fe}, \mathrm{Ni}$ and $\mathrm{Si}$ ). Dissolved oxygen (mgL1) meter of the model: OxyGuard Handy MK II was used in measuring dissolved oxygen and temperature. $\mathrm{PH}$ was measured using $\mathrm{pH}$ meter (model: Hanna Instrument model No. H1 8915 ATC) while salinity was measured using salinometer, model: New S-100 for each of the parameters. The method for analysis of the heavy metals in the water was carried out according to AOAC (1996) and in the fish tissues according to Clesceri (1998) that was carried out using Atomic Absorption Spectrophotometer. Atomic Absorption Spectrophotometer (Model Thermo Electron Corporation, S. Series AA Spectrometer with Gravities furnace, UK,) instrument was used to detect the heavy metals. The concentrations of heavy metals were expressed as mgl-1 for water and $\mu \mathrm{g} g-1$ for fish tissue dry weight. Histopathological examination was made according to the methods implied by (Roberts et al., 1993) and the sections were stained with $\mathrm{H} \& \mathrm{E}$ stain and examined microscopically. Statistical analysis: The data of bacteriological examinations and heavy metal concentrations were statistically analyzed using ANOVA tests according to (SAS, 2004) for detecting the differences in metal concentration among treatments.

\section{Results and discussion}

Water quality is very important factor in the fish hatchery, especially out of heavy metals. Biochar is able by its mechanical treatment of wastewater (i.e. sieves, rakes, followed by a decantation process) followed by a biological cleaning process (i.e. Sewage fields, filtration, trickling filter, submerged bodies, sludge process, nitrate system, decay system) to clear the water out of pollutants (Imhoff et al., 2009). In addition to, shows that organic substances can be removed through absorption with activated carbon. Pollutants also as heavy metals, pesticides and substances from anthropogenic origin remain a huge issue in water can be removed by biochar (Jonathan ,2013). Iwamoto (2012), observed that, the addition of biochar (Iwamoto Biochar for Aquaculture) to the fish and shrimp culture ponds improve the immunity of the fish and shrimp, body weight gain and body weight than the shrimp grown in the ponds without any biochar additives. It worthy to be noted that the increase of survival rate is closely related to the immunity of the fis. Table 2, and figure 2, summarized the weight (WT), Total production (Total PR), Production/female (PPF) and Production/gram (PPG) in broodstock of tilapia in different groups of experiment. The data revealed that the WT were 
Sorur et al.

Table 2. Body weight, total production, production/female and production/gram in broodstock of tilapia in different groups of experiment

\begin{tabular}{|c|c|c|c|c|c|}
\hline Groups & WT & TOTALPR & PPF & PPG & SR \\
\cline { 2 - 6 } & Mean \pm SE & Mean \pm SE & Mean \pm SE & Mean \pm SE & Mean \pm SE \\
\hline G1 & $482.50 \pm 1.44^{\mathrm{a}}$ & $6234.00 \pm 176.89^{\mathrm{bc}}$ & $779.25 \pm 22.11^{\mathrm{bc}}$ & $1.61 \pm 0.05^{\mathrm{bc}}$ & $92.13 \pm 0.52^{\mathrm{b}}$ \\
\hline G2 & $481.67 \pm 1.10^{\mathrm{a}}$ & $6474.00 \pm 14.47^{\mathrm{b}}$ & $809.25 \pm 1.81^{\mathrm{b}}$ & $1.68 \pm 0.00^{\mathrm{b}}$ & $91.13 \pm 0.70^{\mathrm{bcd}}$ \\
\hline G3 & $482.08 \pm 0.75^{\mathrm{a}}$ & $5800.00 \pm 230.94^{\mathrm{bc}}$ & $725.00 \pm 28.87^{\mathrm{bc}}$ & $1.50 \pm 0.06^{\mathrm{cd}}$ & $90.17 \pm 0.73^{\mathrm{cd}}$ \\
\hline G4 & $482.50 \pm 0.72^{\mathrm{a}}$ & $7192.33 \pm 137.70^{\mathrm{a}}$ & $899.00 \pm 17.20^{\mathrm{a}}$ & $1.86 \pm 0.04^{\mathrm{a}}$ & $94.53 \pm 0.43^{\mathrm{a}}$ \\
\hline G5 & $482.50 \pm 0.72^{\mathrm{a}}$ & $5920.33 \pm 119.35^{\mathrm{bc}}$ & $740.02 \pm 14.92^{\mathrm{bc}}$ & $1.53 \pm 0.03^{\mathrm{bcd}}$ & $91.83 \pm 0.26^{\mathrm{bc}}$ \\
\hline G6 & $482.92 \pm 0.75^{\mathrm{a}}$ & $5812.00 \pm 299.74^{\mathrm{bc}}$ & $726.50 \pm 37.47^{\mathrm{bc}}$ & $1.50 \pm 0.08^{\mathrm{cd}}$ & $90.60 \pm 0.52^{\mathrm{bcd}}$ \\
\hline G7 & $482.71 \pm 0.55^{\mathrm{a}}$ & $6132.00 \pm 227.60^{\mathrm{bc}}$ & $728.97 \pm 12.37^{\mathrm{bc}}$ & $1.51 \pm 0.03^{\mathrm{cd}}$ & $91.97 \pm 0.34^{\mathrm{b}}$ \\
\hline G8 & $482.29 \pm 0.91^{\mathrm{a}}$ & $5656.33 \pm 345.88^{\mathrm{c}}$ & $707.00 \pm 43.23^{\mathrm{c}}$ & $1.47 \pm 0.09^{\mathrm{cd}}$ & $90.17 \pm 0.64^{\mathrm{cd}}$ \\
\hline G9 & $482.29 \pm 0.55^{\mathrm{a}}$ & $5681.00 \pm 226.92^{\mathrm{c}}$ & $710.07 \pm 28.35^{\mathrm{c}}$ & $1.41 \pm 0.03^{\mathrm{d}}$ & $89.87 \pm 0.28^{\mathrm{d}}$ \\
\hline
\end{tabular}

Table 3. Heavy metal $(\mathrm{Cu}, \mathrm{Zn}, \mathrm{cd}, \mathrm{Pb}, \mathrm{Hg}$ and $\mathrm{Fe})$ concentrations (mg/litre) in water samples in different groups of experiment

\begin{tabular}{|c|c|c|c|c|c|c|}
\hline Groups & $\mathrm{Cu}$ & $\mathrm{Zn}$ & $\mathrm{Cd}$ & $\mathrm{Pb}$ & $\mathrm{Hg}$ & $\mathrm{Fe}$ \\
\cline { 2 - 7 } & Mean $\pm \mathrm{SE}$ & Mean $\pm \mathrm{SE}$ & Mean $\pm \mathrm{SE}$ & Mean $\pm \mathrm{SE}$ & Mean $\pm \mathrm{SE}$ & Mean $\pm \mathrm{SE}$ \\
\hline G1 & $0.407 \pm 0.035^{\mathrm{b}}$ & $2.207 \pm 0.063^{\mathrm{ab}}$ & $0.032 \pm 0.005^{\mathrm{b}}$ & $0.058 \pm 0.007^{\mathrm{b}}$ & $0.002 \pm 0.000^{\mathrm{b}}$ & $1.219 \pm 0.011^{\mathrm{c}}$ \\
\hline G2 & $0.303 \pm 0.012^{\mathrm{c}}$ & $2.370 \pm 0.112^{\mathrm{a}}$ & $0.037 \pm 0.002 \mathrm{~b}$ & $0.048 \pm 0.005^{\mathrm{b}}$ & $0.003 \pm 0.000^{\mathrm{ab}}$ & $1.289 \pm 0.035 \mathrm{~b}^{\mathrm{c}}$ \\
\hline G3 & $0.024 \pm 0.004^{\mathrm{d}}$ & $2.321 \pm 0.083^{\mathrm{a}}$ & $0.003 \pm 0.001^{\mathrm{c}}$ & $0.014 \pm 0.002^{\mathrm{c}}$ & $0.001 \pm 0.000^{\mathrm{c}}$ & $0.688 \pm 0.028^{\mathrm{d}}$ \\
\hline G4 & $0.019 \pm 0.002^{\mathrm{d}}$ & $2.020 \pm 0.002^{\mathrm{b}}$ & $0.002 \pm 0.000^{\mathrm{c}}$ & $0.017 \pm 0.001^{\mathrm{c}}$ & $0.001 \pm 0.000^{\mathrm{c}}$ & $0.518 \pm 0.030^{\mathrm{e}}$ \\
\hline G5 & $0.277 \pm 0.018^{\mathrm{c}}$ & $2.041 \pm 0.012^{\mathrm{b}}$ & $0.005 \pm 0.001^{\mathrm{c}}$ & $0.053 \pm 0.006^{\mathrm{b}}$ & $0.003 \pm 0.000^{\mathrm{b}}$ & $1.370 \pm 0.059^{\mathrm{b}}$ \\
\hline G6 & $0.035 \pm 0.012^{\mathrm{d}}$ & $2.190 \pm 0.022^{\mathrm{ab}}$ & $0.002 \pm 0.000$ & $0.014 \pm 0.003^{\mathrm{c}}$ & $0.000 \pm 0.000^{\mathrm{c}}$ & $0.448 \pm 0.006 \mathrm{e}^{\mathrm{f}}$ \\
\hline G7 & $0.320 \pm 0.021^{\mathrm{c}}$ & $2.249 \pm 0.032^{\mathrm{ab}}$ & $0.027 \pm 0.008^{\mathrm{b}}$ & $0.045 \pm 0.004^{\mathrm{b}}$ & $0.002 \pm 0.000^{\mathrm{b}}$ & $1.354 \pm 0.035^{\mathrm{b}}$ \\
\hline G8 & $0.020 \pm 0.008^{\mathrm{d}}$ & $2.242 \pm 0.030^{\mathrm{ab}}$ & $0.001 \pm 0.000^{\mathrm{c}}$ & $0.012 \pm 0.001^{\mathrm{c}}$ & $0.000 \pm 0.000^{\mathrm{c}}$ & $0.381 \pm 0.012^{\mathrm{f}}$ \\
\hline G9 & $0.600 \pm 0.040^{\mathrm{a}}$ & $2.377 \pm 0.148^{\mathrm{a}}$ & $0.074 \pm 0.006^{\mathrm{a}}$ & $0.094 \pm 0.004^{\mathrm{a}}$ & $0.004 \pm 0.000^{\mathrm{a}}$ & $1.568 \pm 0.040^{\mathrm{a}}$ \\
\hline
\end{tabular}

highest in Groups 6 and 7, while TOTALPR in Groups 1, 2, 4 and 7, the
PPF in Groups 1, 2 and 7 and the PPG were highest in Groups 1, 2 and 7.On the 
other hand the other groups were equals in the values. The results of reproduction in broodstock of tilapia in presence of biochar is strongly related to absence of stress and good quality of water during hatchery which directly improvement of spawning. The different authors reported the biochar has many potential benefits on aquaculture process (Lehmann et al., 2011; Gascó et al., 2012 and Paz Ferreiro et al., 2014;). Also, biochar addition to the water will cause alterations in water quality (PazFerreiro and $\mathrm{Fu}, 2014$ ) with the potential to increase agricultural yields (Jeffery et al., 2011; Liu et al., 2013). In addition to enhance biochar' ability to immobilize heavy metals (Lima et al., 2014).Interaction between biochar and heavy metal it is necessary to note that biochars act on the bioavailable fraction of soil heavy metals and that they can reduce

Tables 3 and 4 illustrated the heavy metals in the water in different groups of experiment. The data revealed that the heavy metals were lowest in the Groups 3, 4, 5, 6 and 8.On the same manner the other groups the same heavy metals were higher than the treated groups but in the same time is lower than the permissible limits. Tables (3 and 4) cleared the significant differences of the levels of different heavy metals in water among different treated groups $(\mathrm{P}<$ $0.01)$. The results cleared that the zinc level showed a higher level in control group (2.38) and the lower level observed biochar saw dust (2.02), the level of copper showed a higher level in control group (0.60) and the lower level observed in group 8 that treated with sand + break dust + raw rice husk. (0.02). The iron level showed a higher level in control group (1.57) and the lower level observed in group 6 that treated with sand + biochar rice husk + biochar saw dust. (0.16). The Nickel level showed a higher level in control group (2.26) and the lower level observed in group 8 that treated with sand + break dust + raw rice husk. The also their hatchability (Beesley and Marmiroli, 2011 and Lu et al., 2012). Fry survival rate had been increased, may be due to the improvement induced by using of biochar. Alexander and Stewart, 2001 and An et al., 2009 reported that Flavobacterium isolates have been shown to have biocontrol capabilities and to elicit resistance response of plants to different diseases during used of biochar. Graber et al. (2010) also, isolated a number of bacteria with identity to known biocontrol agents, induced resistance agents and growth promoters ( 15 out of 20 total isolates) from the root zone of biocharamended pepper plants where promotion of plant growth and induction of systemic resistance against Fungal foliar diseases occurred simultaneously (Elad et al., 2010 and Graber et al., 2010).

mercury level showed a higher level in control group (0.0043) and the lower level observed in group 8 that treated with sand + break dust + raw rice husk. (0.0004) and group 6 that treated with Biochar rice husk + Biochar saw dust (0.0004). The cadmium level showed a higher level in group A (0.074) and the lower level observed in group $8(0.0013)$ that treated with Sand + Break dust + raw rice husk. The zinc level showed a higher level in control group (0.09) and the lower level observed in the group (3) that treated with Sand + Biochar saw dust + Biochar saw dust, group (4) that treated with Sand + Break dust + Biochar saw dust, group (6) and group (8) as its level reached to $(0.01)$. The silicon level showed a higher level in group (2) (2.22) and the lower level observed in group (8) that treated with Sand + Break dust + raw rice husks its level reached to (0.14). The arsenic level showed a higher level in control group (0.0013), group 1 (0.0003), group (3) that treated with Sand + Biochar saw dust + Biochar saw dust as its level reached to $(0.0003)$ and the lower level reached to (0) 
Table 4. Heavy metal (Ni, Si and Chromium) concentrations (mg/litre) in water samples in different groups of experiment

\begin{tabular}{|c|c|c|c|}
\hline \multirow{2}{*}{ Groups } & Ni & Si & chromium \\
\cline { 2 - 4 } & Mean \pm SE & Mean \pm SE & Mean \pm SE \\
\hline G1 & $1.330 \pm 0.059 \mathrm{c}$ & $1.947 \pm 0.176 \mathrm{~b}$ & $0.069 \pm 0.008 \mathrm{a}$ \\
\hline G2 & $1.783 \pm 0.063 \mathrm{~b}$ & $2.223 \pm 0.167 \mathrm{a}$ & $0.061 \pm 0.004 \mathrm{a}$ \\
\hline G3 & $0.794 \pm 0.070 \mathrm{e}$ & $0.233 \pm 0.065 \mathrm{~d}$ & $0.009 \pm 0.002 \mathrm{c}$ \\
\hline G4 & $0.497 \pm 0.041 \mathrm{f}$ & $0.230 \pm 0.023 \mathrm{~d}$ & $0.012 \pm 0.001 \mathrm{bc}$ \\
\hline G5 & $1.197 \pm 0.068 \mathrm{~cd}$ & $1.397 \pm 0.055 \mathrm{c}$ & $0.066 \pm 0.005 \mathrm{a}$ \\
\hline G6 & $0.161 \pm 0.045 \mathrm{~g}$ & $0.260 \pm 0.025 \mathrm{~d}$ & $0.007 \pm 0.000 \mathrm{c}$ \\
\hline G7 & $1.073 \pm 0.143 \mathrm{~d}$ & $1.733 \pm 0.046 \mathrm{~b}$ & $0.049 \pm 0.005 \mathrm{a}$ \\
\hline G8 & $0.177 \pm 0.030 \mathrm{~g}$ & $0.147 \pm 0.012 \mathrm{~d}$ & $0.008 \pm 0.001 \mathrm{c}$ \\
\hline G9 & $2.260 \pm 0.137 \mathrm{a}$ & $1.220 \pm 0.067 \mathrm{c}$ & $0.040 \pm 0.027 \mathrm{ab}$ \\
\hline
\end{tabular}

Table 5. Heavy metals $(\mathrm{Cu}, \mathrm{Zn}, \mathrm{Cd}, \mathrm{Pb}, \mathrm{Hg}$ and $\mathrm{Fe}$ ) concentrations ( $\mu \mathrm{g} / \mathrm{g}$ dry wt.) in liver of Oreochromis niloticus in different groups of experiment

\begin{tabular}{|c|c|c|c|c|c|c|}
\hline Groups & $\mathrm{Cu}$ & $\mathrm{Zn}$ & $\mathrm{Cd}$ & $\mathrm{Pb}$ & $\mathrm{Hg}$ & $\mathrm{Fe}$ \\
\cline { 2 - 7 } & Mean \pm SE & Mean \pm SE & Mean \pm SE & Mean \pm SE & Mean \pm SE & Mean \pm SE \\
\hline G1 & $33.93 \pm 0.84 \mathrm{a}$ & $176.63 \pm 8.77 \mathrm{a}$ & $0.23 \pm 0.01 \mathrm{a}$ & $0.45 \pm 0.02 \mathrm{a}$ & $1.60 \pm 0.10 \mathrm{a}$ & $138.42 \pm 7.47 \mathrm{a}$ \\
\hline G2 & $29.01 \pm 1.12 \mathrm{~b}$ & $140.76 \pm 1.86 \mathrm{~b}$ & $0.25 \pm 0.01 \mathrm{a}$ & $0.46 \pm 0.02 \mathrm{a}$ & $1.20 \pm 0.04 \mathrm{bc}$ & $118.44 \pm 1.35 \mathrm{~b}$ \\
\hline G3 & $26.17 \pm 1.79 \mathrm{~b}$ & $122.58 \pm 1.58 \mathrm{c}$ & $0.22 \pm 0.00 \mathrm{a}$ & $0.41 \pm 0.01 \mathrm{a}$ & $1.42 \pm 0.06 \mathrm{ab}$ & $102.82 \pm 2.22 \mathrm{c}$ \\
\hline G4 & $3.93 \pm 1.24 \mathrm{f}$ & $62.63 \pm 1.62 \mathrm{~h}$ & $0.13 \pm 0.02 \mathrm{~b}$ & $0.23 \pm 0.01 \mathrm{c}$ & $0.33 \pm 0.20 \mathrm{~d}$ & $38.17 \pm 3.15 \mathrm{f}$ \\
\hline G5 & $9.19 \pm 0.31 \mathrm{de}$ & $73.61 \pm 4.13 \mathrm{gh}$ & $0.12 \pm 0.01 \mathrm{bc}$ & $0.29 \pm 0.02 \mathrm{~b}$ & $0.33 \pm 0.20 \mathrm{~d}$ & $56.73 \pm 3.39 \mathrm{e}$ \\
\hline G6 & $21.05 \pm 0.94 \mathrm{c}$ & $108.70 \pm 2.14 \mathrm{~d}$ & $0.23 \pm 0.00 \mathrm{a}$ & $0.43 \pm 0.01 \mathrm{a}$ & $1.07 \pm 0.03 \mathrm{c}$ & $115.58 \pm 5.03 \mathrm{bc}$ \\
\hline G7 & $20.55 \pm 0.95 \mathrm{c}$ & $101.17 \pm 4.50 \mathrm{de}$ & $0.22 \pm 0.01 \mathrm{a}$ & $0.45 \pm 0.02 \mathrm{a}$ & $1.11 \pm 0.06 \mathrm{bc}$ & $110.45 \pm 6.08 \mathrm{bc}$ \\
\hline G8 & $7.77 \pm 0.81 \mathrm{e}$ & $85.34 \pm 4.08 \mathrm{fg}$ & $0.10 \pm 0.02 \mathrm{bc}$ & $0.22 \pm 0.00 \mathrm{c}$ & $0.08 \pm 0.03 \mathrm{~d}$ & $66.72 \pm 2.89 \mathrm{de}$ \\
\hline G9 & $11.91 \pm 1.16 \mathrm{~d}$ & $93.88 \pm 2.55 \mathrm{ef}$ & $0.09 \pm 0.02 \mathrm{c}$ & $0.26 \pm 0.02 \mathrm{bc}$ & $0.16 \pm 0.06 \mathrm{~d}$ & $74.77 \pm 6.62 \mathrm{~d}$ \\
\hline
\end{tabular}


that observed in the groups (3), (4) that treated with Sand + Break dust + Biochar saw dust, (6) that treated with Sand + Biochar rice husk + Biochar saw dust, group (7) that treated with Sand + Break dust + Biochar rice husk and group (8) that treated with Sand + Break dust + raw rice husk. The chromium level showed a higher level that, observed in control group (0.04), and group (7) that treated with Sand + Break dust + Biochar rice husk and its level reached to (0.04) . While, the lower level observed in group (8) that treated with Sand + Break dust + raw rice husks its level reached to (0.007). The manganese level showed a higher level in control group (0.07) and the lower level that observed in group 3 and 4 as its level reached to (0.01). Our results cleared that, the biochar addition to the fish ponds decreasing the level of heavy metals in water due to the biochar absorbed the heavy metals in the water with its reduction level than the other treatment especially the biochar dust than the other types of biochar. Our results agreed with those of (Silber et al., 2010 and Yang et al., 2014), where they observed that, the addition of biochar to fish ponds reduce the level of heavy metals in fish production ponds.

Table, 5 illustrated the heavy metals in the liver in different groups of experiment. The data revealed that the heavy metals were lowest in the Groups 3, 4, 5, 6 and 8.On the same manner the other groups the same heavy metals were higher than the treated groups but in the same time is lower than the permissible limits. Table (14) cleared the significant differences of the level of heavy metals in liver among different treatments among examined fish product samples. Zinc level showed a higher level in biocharrice husk (85.10) followed by raw rice husk (73.66) and the lower level of zinc observed in the group treated with Biochar saw dust (0.34) and red break dust (3.15) . The copper level showed a high level in raw rice husk (85.33) and biochar rice husk (46.33) and the lower level observed in biochar saw dust (4.41) and red break (0).
The iron level showed a higher level in raw rice husk (139.85) followed by Biochar rice husk (96.59) and the lower level observed in biochar saw dust (0.54). The nickel level show a high level in raw rice husk (1.93) and the lower level of nickel observed in the biochar rice husk (0.65). The mercury level not recorded among the all treatments and it level reached to (0). The cadmium level not recorded in all treatments and its level reached to (0) but in raw rice husk reached to (0.06). The lead level not recorded in all treated groups except in red break treated groups (18.05). The silicon level showed a higher level in sand treated groups (671.17) and the lower level observed in biochar saw dust (78.25). The Arsenic level not recorded among the all treatments and it level reached to (0). The chromium level in all groups showed a level of (0) except in the groups treated with raw rice husk (44.19) and Biochar rice husk (41.07). The manganese level showed a higher level in Biochar saw dust (720.12) and the lower manganese level observed in sand treated group (173.39). Our results concluded that, the biochar increase the level of secretion of heavy metals in fish products than the other treatments especially the rice husk biochar and saw dust biochar. This results attributed to the biochar activated the fish viability and immunity also the biochar contain a higher level of heavy metals especially arsenic, iron and nickel. Our results agreed with those of Fang et al. (2014) and Zhang et al. (2012), where they reported that the biochar improve the secretion of heavy metals in fish products due to improving the fish viability and digestibility of the foods.

\section{References}

Amlacher,E.1970.Textbook of fish diseases, T.E.S. Publication, New Jersey. USA, P. 117-135.

APHA,1995.American Public Health AssociationStandard Methods for the Examination of Water and Wastewater.19thEds., Washington DC. 
AOAC, 1996. Official Methods of Analysis. 16th Edition, Association of Official Analytical Chemists, Washington DC.

Clesceri, L.S.; Greenberg, A.E. and Eaton, A.D. 1998. Standard methods for the examination of water and wastewater. 20th ed. American Public Health Association, Washington, 1998; 1325 p.

Dias,B.O.; Silva,C.A.; Higashikawa,F.S.; R oig,A.and Sánchez-Monedero, M.A. 2014. Bioresour Technol. 2010 Feb; 101(4):1239-46. .

Fang,C. Zhang,T.; Li,P.;Jiang,R.F.and Wan

g, Y.C. 2014. Application of magnesium modified corn biochar for phosphorus removal and recovery from Swine wastewater. Int J Environ Res Public Health. 2014 Sep 5; 11(9):9217-37.

Graber, E.R.; Meller-Harel, Y.; Kolton, M.; Cytryn, E.; Silber, A.; Rav David, D.; Tsechansky, L.; Borenshtein, M. and Elad,Y. 2010. Biochar impact on development and productivity of pepper and tomato grown in freighted soilless media. Plant and Soil 337, 481-496.

Greenberg, M.T. Buzrul, S.; Ozturk, P.; Alpas, H. and Akcelik, M. 1992. Thermal and chemical inactivation of lactococci bacteriophage. LWT Food Science and Technology.40, 1671 1677.

International Biochar Initiative, 2014. Why biochar. (C) 2014 International Biochar Initiative

Li, M.; Lou, Z.;Wang, Y.; Liu, Q.; Zhang, Y.; Zhou, J. and Qian, G. 2014. Alkali and alkaline earth metallic (AAEM) species leaching and $\mathrm{Cu}$ (II) sorption by biochar. Chemosphere.2014 Sep 3; 119C: $778-785$.
Li, F.; Cao, X.; Zhao, L.; Wang, J. and Ding, Z. 2014. Effects of Mineral Additives on Biochar Formation:CarbonRetentio n, Stability, and Properties. Environ Sci Technol. Sep 9.[Epub ahead of print]

Major, J.;Rondon,M.; Molina, D.; Riha, S.J.and Lehmann, J. 2010. Maize yield and nutrition during 4 years after biochar application to a Colombian savanna oxisol. Plant and Soil 333, 117-128.

Pietikainen, J.; Kiikkila, J. and Fritze, H. 2000. Charcoal as a habitat for microbes and its effect on the microbial community of the underlying humus.Oikos89, 231-242.

Reverchon,F.; Yang,H.; Ho,T.Y.; Yan,G.;W ang,J.;Xu, Z.; Chen, C.and Zhang, D. 2014. A preliminary assessment of the potential of using an acaciabiocharsystem for spent mine site rehabilitation. Environ SciPollut Res Int. 2014 Aug 30. [Epub ahead of print]

Roberts,R.J.;Willoughby,L.G.and Chinabut, S.1993. Mycotic aspects of epizootic ulcerative syndrome (EUS) of Asian fishes. Journal of fish Diseases 16(3):169-184

Roy, M. and McDonald, L. M. 2014. Metal uptake in plants and health risk assessments in metal-contaminated smelter soils, Land Degrad. De

SAS, 2004. Statistical analysis system. SAS user's Guide SAS incorporation Institute.

Schmidt, P. S. 2014.55 uses of biochar. Journal for ecology, winegrowing and climate farming. Ithaca. From the Ithaka Journal article:

Silber, A.;Levkovitch,I. and Graber, E.R. 2010. pH-Dependent mineral release and surface properties of 
cornstrawbiochar: agronomic implications. Environmental Science \& Technology 44, 9318 - 9323.

Vaccari,F.P.;Baronti, S.; Lugato, E.; Genesio, L.; Castaldi, S.; Fornasier,F. and Miglietta,F. 2011. Biochar as a strategy to sequester carbon and increase yield in durum wheat. European Journal of Agronomy 34, 231-238.

Wardle, D.A.; Zackrisson,O. and Nilsson, M.C.1998. The charcoal effect in Boreal forests: mechanisms and ecological consequences. Oecologia115, 419-426.

Warnock, D.D.; Lehmann,J.; Kuyper, T.W. and Rillig,M.C.2007.Mycorrhizal responses to biochar in soil - concepts and mechanisms.Plant and Soil 300,920.

Yamato, M.; Okimori, Y.; Wibowo,I.F.; Anshori, S. and Ogawa, M. 2006. Effects of the application of charred bark of Acacia mangium on the yield of maize, cowpea and peanut, and soil chemical properties in South Sumatra, Indonesia. .Soil Science and Plant Nutrition 52, 489-495.
Yang, Y.; Wei,Z.; Zhang,X.; Chen, X.; Yue, D.; Yin, Q.; Xiao, L.and Yang, L. 2014.Biochar from Alternanthera philoxeroides could remove $\mathrm{Pb}$ (II) efficiently. Bioresour Technol. 2014 Aug 9; 171C: 227-232.

Zheng, R. L., Cai, C., Liang, J. H., Huang, Q., Chen, Z.;Huang, Y. Z.; Arp, H. P. H. and Sun, G. X. 2012. The effects of biochars from rice residue on the formation of iron plaque and the accumulation of $\mathrm{Cd}, \mathrm{Zn}, \mathrm{Pb}$, As in rice (Oryza sativa L.) seedlings, Chemosphere, 89, 856-863.

Zhang, S. and Sun, M. 2014. Yersiniosis American Association of Zoo Veterinarians Infectious Disease Committee Manual. DVM, PhD.

Zehra, I.; Kauser, T.; Zahir, E. and Naqvi, I. I. 2003. Determination of $\mathrm{Cu}, \mathrm{Cd}, \mathrm{Pb}$ and $\mathrm{Zn}$ Concentration in Edible Marine Fish Acanthopagurus berda (DANDYA) Along Baluchistan Coast-Pakistan. International journal of agriculture \& biology 1: $80-82$. 